\title{
Sustainable development of the field of operational services on innovative basis of smart technologies
}

\author{
Anna Romanova ${ }^{1[000-0002-4614-0872]}$, Evgeniya Ilina $^{1 *[0000-0002-5209-8703]}$ \\ ${ }^{1}$ Kazan State University of Architecture and Civil Engineering ,420043,Zelenayast.,Kazan, Russia \\ E-mail:Ilina19091982@mail.ru
}

\begin{abstract}
The article deals with the problems of sustainable development of the economy. In modern conditions, the problem of improving the housing and communal services sphere largely depends on the introduction of the latest smart technologies. Such technologies are designed to improve energy efficiency, save resources, simplify work processes, collect relevant information and digitalize the housing and communal services sector as a whole. The experience of the practical use of smart technologies as an innovative energy efficiency solution for apartment buildings is considered. The purpose of the study is to develop innovative approaches to managing the field of operational services and to improve the efficiency of the housing and communal services industry based on smart technologies.
\end{abstract}

Keywords: smart technologies, sustainable development, management of an apartment building, economic feasibility, energy efficiency.

\section{Introduction}

In modern conditions, improving the sphere of housing and communal services by means of smart technologies is a mandatory process, both in new construction and in the renovation of old housing stock. The use of smart technologies allows making the service, house and even the city smart. An integral part of the smart cityconcept is smart housing and communal services. It is responsible for the automation of housing and communal services for accurate and one-time transmission of meter readings (meters), control of the operation and condition of equipment, transparency of the operation of housing and communal services, prevention of emergencies, etc. This transformation improves the quality of life by making the urban environment safe and comfortable. First of all, smart technologies are human-oriented.

Numerous works of foreign and domestic scientists are devoted to the problems of sustainable development of cities and houses. The main directions of research in the field of management of smart cities and houses systems are determined by the works of scientists A. Meijer, M. P. R. Bolívar [1], A. Caragliu, Del Bo, C., Nijkamp, P. [2], who assessed the

* Corresponding author: Ilina19091982@mail.ru 
intellectual infrastructure for the development of urban infrastructure. Smart technologiesimplementation processesfor urban development are disclosed in the works of Araral E. [3] and Gimpel H., Graf V., Graf-Drasch V. [4]. Energy efficiency for sustainable development is studied by Chen M., Sinha A., Hu K., Shah M. I. [5]. Pelli P. worked at innovations in the service sector and green building [6]. The relationship between the economy and climate change in solving the problems of energy efficient repair was investigated by Mikulić D., Slijepčević S., Buturac G. [7]. Approaches to assessing the current energy efficiency management potential are disclosed in the works of Xia Z., Ge Song Q. A [8]. The experimental campaign by Synnefa A., Vasilakopoulou K., Santamouris M. developed for measuring and confirming energy savings in the house before and after the complex process of modernization of energy consumption seems to be interesting [9]. The works of scientists D. D. Kim, H. S. Suh [10] are devoted to the development of a model for predicting energy consumption for heating and cooling multistorey residential buildings, taking into account the design parameters. The study of the thermal energy accumulation for space heating and hot water supply in individual residential buildings is the subject of the works of such researchers as Kuznik F., Opel O., Wolfgang K. L. Ruck (11). Information modeling of the capital construction market and the impact of residents on energy performance is studied in the works of Bakhareva O. V., Romanova A. I., et al [12], Gilani S., O'Brien W., Gunay H. B. [13].

Burkeev D. O., Romanova A. I., Murafa A. A., Maksimchuk O. V., Voronin A. . studied the introduction of innovative technologies in the field of facilities maintenance in Russia [14]. Methods for managing operational services in the context of sustainable development of intelligent technologies were studied by Ilina E. V., Romanova A. I. [15]. Authors of scientific works Afanasyeva A. N., Fedorova S. F. dealt with issues of housing provision in conditions of sustainable development [16]. The development of the real estate operational cycle was considered in the works of Ilina E. V., Romanova A. I., Maksimchuk O. V., Voronin A. V. [17]. The formation of sustainable development goals can be traced in the work of Rao Y. [18]. Despite numerous studies of the concept of sustainable development, some authors criticize it; the information can be found in the works of S. Kwatra, A. Kumar, P. Sharma [19]. The authors touched upon the problems and prospects of the field of operational services and construction efficiency: Romanova A. I., Zagidullina G. M., Afanasyeva A. N., Hkairetdinova R. S. [20] and Elvira Shagiakhmetova other [21, 22]. However, despite the presence of a broad theoretical and methodological generalization and practical solutions, there is a lack of practical examples demonstrating the effectiveness of modern solutions to the problem of optimizing the operational services of an apartment building and increasing the level of their smart management. The purpose of such events is, on the one hand, the development of a house as a modern facility; on the other hand, with constant growth of utilities, there is an urgent need to reduce energy costs (one of the main conditions for a sustainable economy), and, as a consequence, economic benefits.

\section{Methods}

To calculate the economic efficiency of smart technology in the operational services of an apartment building, the following methods were used: analytics of the universal service GIS Housing and Communal Services of the Russian Federation (State Information System of Housing and Communal Services of the Russian Federation); analysis of the program for digital development of the economy, developed by the Ministry of Construction of the Russian Federation; questioning residents of houses; conducting a «focus group» with residents of the houses. Diverse monitoring of information made it possible to offer the installation of individual heating points with a weather control unitto users of operational 
services. This technology is a heating system equipped with temperature sensors, an electrically driven control valve, a circulation pump, a check valve, an electric control cabinet (with a program controller), shut-off and control valves, filters and others. A tangible effect of saving thermal energy in heat supply systems (up to 20-30\%) can be achieved by meansof automatic regulation of heat consumption. Automation tasks can be most fully and effectively implemented with the help of individual heating units of buildings (hereinafter IHU) with the ability to regulate heat consumption at the request of the consumer, depending on the outside temperature, the purpose of the object, etc., when the outside air temperature (weather compensation) changes, as well as due to the possibility of automatic temperature reduction inside the building at night and on weekends (for office buildings, academic buildings, etc.).

The main directions of optimum use and saving of energy resources when using IHUare:

- improvement of technological processes,

- improvement of equipment,

- high efficiency,

- long-term operation,

- reduction of operating costs up to about 40-60\%,

- reduction of heat energy loss up to $15 \%$,

- silent work,

- compactness.

In each house, when the heating network is put into operation, an individual heating point is installed. construction scheme with a description of the equipment used in them.

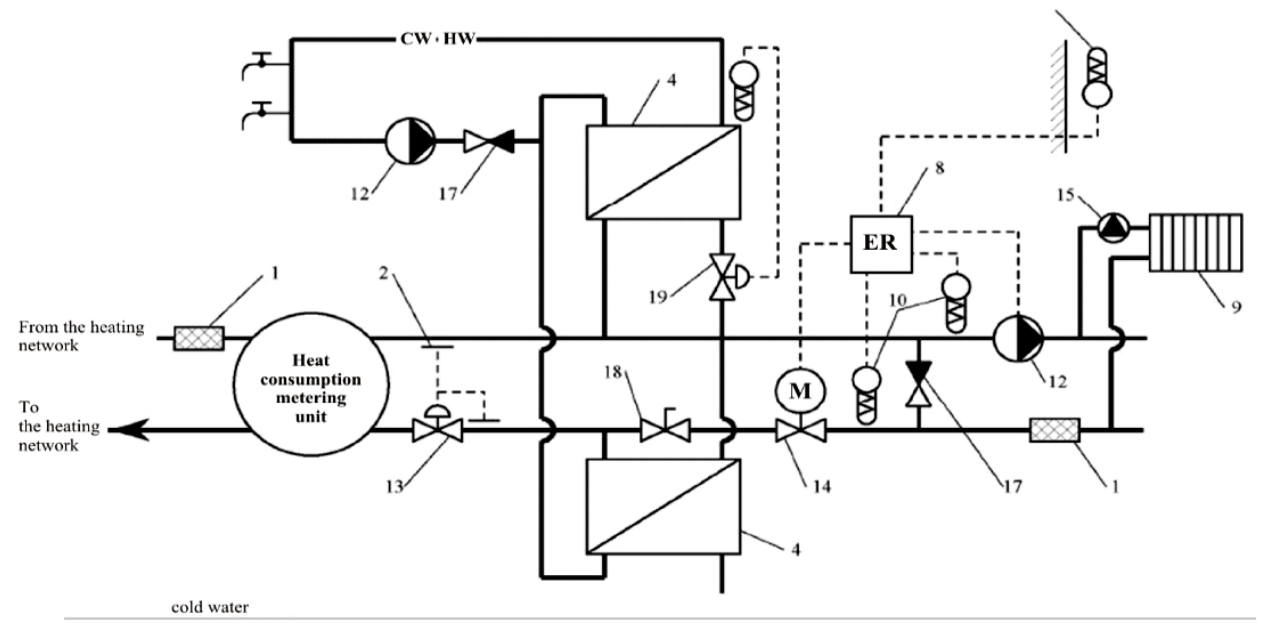

Fig. 1. Automationscheme of a closed centralized heating system of a building with dependent connection of heating to heating networks, with a direct-acting regulator for hot water supply. 1) mesh filter; 2) water pressure sensor in the pipeline; 3) water heater for the hot water supply system; 4) electronic regulator; 5) heating device; 6) water temperature sensor in the pipeline; 7) outside air temperature sensor; 8) pump; 9) differential pressure regulator; 10) a control valve with an electric drive; 11) radiator thermostat; 12) check valve; 13) manual balancing valve; 14) direct-acting temperature controller.

A single-channel electronic controller (Fig. 1), receiving information from the outside air temperature sensor and temperature sensors of the heating medium in the direct and return pipelines of the heating system, regulates the flow and temperature of the heating medium 
for the heating system by the valve and pump of the heating systemcontrol. It is possible to correct the regulation process using an indoor temperature sensor additionally installed in the room. The water temperature in the DHW system in this scheme is maintained by a direct-acting regulator, which is a combination of a universal thermoelement and a control valve of the required diameter. It is possible to use a second electronic controller to regulate the hot water temperature instead of a direct-acting controller. A constant differential pressure across the building inlet is ensured by a differential pressure regulator. Electronic controllers are designed for automatic regulation of the temperature and flow rate of the heating agent in heating and hot water supply systems. The electronic controller controls heating and hot water systems in accordance with the user's settings (temperature setting, air temperature drop at night, etc.).It uses information from the coolant temperature sensors and outdoor and indoor air temperature sensors entering its inputs, and acts on the control object via thyristor or relay outputs to control the pump and control valve drive. For daily (day / night) and weekly (work / weekends) regulation, the electronic regulator is equipped with a timer, which can be built-in or separate. It allows changing (increasing / decreasing) the temperature of the coolant depending on the set time. We assume that, all other things being equal, operational services using this implementation methodology will improve energy efficiency, resource conservation and economic benefits. The installation of these smart technologies can be used by public authorities to save resources, as well as when developing appropriate solutions in the field of sustainable development of territories.

\section{Results and discussion}

As an example of the introduction of smart technologies for the sustainable development of the economy and management, we will calculate the economic benefits when using the weather control unit in the apartment building 11, Chernomorskaya Street, Moskovsky District, Kazan. According to the tariffs for heat energy (Table 1) in Kazan and indications for the general house metering device (Table 2), we will calculate the savings for the heating season 2018-2019 after the installation of the selected model of the weather control unit, in comparison with the heating season 2017-2018. We will also calculate the energy efficiency of this equipment, determining the amount of Gcal saved during the heating season, by regulating the temperature regime for supplying heat to the house. In comparison with the heating season of 2017-2018, we will determine the volume of overheating in Gcal. The calculation results are presented in Table 2.

The house we are considering is number 11, Chernomorskaya Street is served by JSC Tatenergo. Reducing the annual cost of heat expression:

$$
3_{\mathrm{t}}=\left(Q_{1}-Q_{2}\right) * C_{t}
$$

where:

$\mathrm{Q}_{1}$ - heat consumption for the season 2017-2018;

$\mathrm{Q}_{2}$ - heat consumption for the season 2018-2019;

$\mathrm{C}_{\mathrm{t}}$ - tariff for heat energy, rubles / Gcal. 
Table 1. Tariffs for heat energy (heating) supplied to the population of Kazan, Republic of Tatarstan in 2019.

\begin{tabular}{|c|c|c|c|}
\hline Name of service & $\begin{array}{c}\text { Tariff from } \\
01.07 .2018 \text { to } \\
31.12 .2018 \\
\text { RUB / Gcal }\end{array}$ & $\begin{array}{c}\text { Tariff from } \\
01.01 .2019 \\
\text { to } \\
30.06 .2019 \\
\text { RUB / Gcal }\end{array}$ & Base \\
\hline & 1 & 2 & \\
\hline $\begin{array}{l}\text { Heating (JSC } \\
\text { «Tatenergo») }\end{array}$ & 1670.07 & 1691.38 & $\begin{array}{l}\text { 1) Resolution of the State } \\
\text { Committee of the Republic of } \\
\text { Tatarstan on Tariffs dated } \\
15.12 .2017 \text { No. } 5-83 / \text { te } \\
\text { 2) Resolution of the State } \\
\text { Committee of the Republic of } \\
\text { Tatarstanon Tariffs dated } \\
\text { 19.12.2018 No. 5-91/te }\end{array}$ \\
\hline $\begin{array}{l}\text { Heating (JSC } \\
\text { «Kazenergo») }\end{array}$ & 1678.77 & 1766.98 & $\begin{array}{l}\text { 1) Resolution of the State } \\
\text { Committee of the Republic of } \\
\text { Tatarstan on Tariffs dated } \\
14.12 .2017 \text { № 5-74/ te } \\
\text { 2) Resolution of the State } \\
\text { Committee of the Republic of } \\
\text { Tatarstanon Tariffs dated oT } \\
18.12 .2018 \text { № 5-95/ te }\end{array}$ \\
\hline
\end{tabular}

Calculation of heat savings by month:

$3_{\text {okt }}=59.42-104.78=-45.36 \mathrm{Gcal}$;

$3_{\text {nov }}=76.57-119.99=-43.42 \mathrm{Gcal} ;$

$3_{\text {dec }}=87.11-140.38=-53.27 \mathrm{Gcal} ;$

$3_{\text {jan }}=118.78-164.03=-45.25 \mathrm{Gcal}$;

$3_{f e b}=105.84-191.11=-85.27 \mathrm{Gcal} ;$

$3_{\text {marc } \square}=81.01-137.41=-56.40 \mathrm{Gcal}$;

$3_{\text {apr }}=105.84-191.11=-85.27$ Gcal.

Total Gcal savings for the heating season are:

$-45.36-43.42-53.27-45.25-85.27-56.42-85.27=-362.07$ Gcal.

Let's calculate the savings in monetary terms from October 2018 to December 2018:

$3_{t}=(-45.36-43.42-53.27) * 1670.07=-237233,44 \mathrm{rub}$.

Let's calculate the savings in monetary terms from January 2019to April 2019:

$3_{t}=(-45.25-85.27-56.42-33.10) * 1691.38=-372137.42 \mathrm{rub}$.

Total for the heating season:

$3_{t}=237230.44+372137.428=-609370.86$ rub.

Let's calculate the savings for $1 \mathrm{~m}^{2}$ using the formula:

$$
3_{\text {t.m2 }}=\frac{3_{\text {t.month }}}{S_{\text {home }}}
$$

$3_{\text {t.okt }}=\frac{-75754.37}{3462.4}=-21.88 \mathrm{rub} / \mathrm{m}^{2}$; 
$3_{\text {t.nov }}=\frac{-72514.44}{3462.4}=-20.94 \mathrm{rub} / \mathrm{m}^{2} ;$

$3_{\text {t.dec }}=\frac{-88964.63}{3462.4}=-25.69 \mathrm{rub} / \mathrm{m}^{2}$;

$3_{\text {t.jan }}=\frac{-76534.95}{3462.4}=-22.10 \mathrm{rub} / \mathrm{m}^{2}$;

$3_{\text {t.feb }}=\frac{-144223.97}{3462.4}=-\frac{41.65 \mathrm{rub}}{\mathrm{m}^{2}}$;

$3_{\text {t.march }}=\frac{-95393.83}{3462.4}=-27.55 \mathrm{rub} / \mathrm{m}^{2}$;

$3_{\text {t.apr }}=\frac{-55984.68}{3462.4}=-16.17 \mathrm{rub} / \mathrm{m}^{2}$;

Total:

$-21.88-20.94-25.69-22.10-41.65-27.55-16.17=-176 \mathrm{rub} / \mathrm{m}^{2}$;

The savings for the heating season 2017-2018 after the installation of the weather control unit in comparison with the heating season 2018-2019 amounted to $30 \mathrm{~m}^{2}$ in a 1room apartment:

In a 2-room apartment $45 \mathrm{~m}^{2}$ :

$$
-176 * 30=-5279.9 \text { rub. }
$$

In a 3-room apartment $60 \mathrm{~m}^{2}$ :

$$
-176 * 45=-7919.85 \text { rub. }
$$

$$
-176 * 60=-10559.8 \text { rub. }
$$

Let's determine the payback period of the weather control unit installed in the house number 11 Chernomorskaya Street:

$T=\frac{410000}{609370.86-41000}=0.63$ year.

The translated result is 5.5 months.

Table 2. The results of the study of the weather control unit installed in the house 11, Chernomorskaya street, Kazan.

\begin{tabular}{|c|c|c|c|c|c|}
\hline \multirow{2}{*}{ Month } & \multirow{2}{*}{$\begin{array}{c}\text { Consumption } \\
\text { 2017-2018, } \\
\text { Gcal }\end{array}$} & $\begin{array}{c}\text { Consumption } \\
\text { 2018-2019, Gcal }\end{array}$ & \multicolumn{2}{|c|}{$\begin{array}{c}\text { Difference (-) savings; } \\
(+) \text { overrun }\end{array}$} & \multirow{2}{*}{$\begin{array}{c}\text { Savings, } \\
\text { rub / } \mathrm{m}^{2}\end{array}$} \\
\cline { 4 - 5 } & 2 & 3 & $4=3-2$ & $5=4 *$ Tariff & 7 \\
\hline October & 104.78 & 59.42 & -45.36 & -75754.37 & -21.88 \\
\hline November & 119.99 & 76.57 & -43.42 & -72514.44 & -20.94 \\
\hline December & 140.38 & 87.11 & -53.27 & -88964.63 & -25.69 \\
\hline January & 164.03 & 118.78 & -45.25 & -76534.95 & -22.10 \\
\hline February & 191.11 & 105.84 & -85.27 & -144223.97 & -41.65 \\
\hline March & 137.41 & 81.01 & -56.40 & -95393.83 & -27.55 \\
\hline April & 105.56 & 72.46 & -33.10 & -55984.68 & -16.17 \\
\hline Total & 963,26 & 601,19 & $-362,07$ & $-609370,86$ & $-190,47$ \\
\hline
\end{tabular}


The results of this study (Table 2) indicate that the weather control units allow residents to save money from the first heating season (if the weather control unit was installed in the non-heating season).

\section{Discussions}

The mechanism for the smart technologiesimplementation and the digitalization of the entire urban economy will ensure a decent and modern standard of living for citizens. This will make it possible to prevent various emergencies caused by network breakdowns, as well as collect and analyze relevant information necessary for work. To achieve the maximum result in digitalization and the use of other smart technologies will allow updating and analyzing of smart solutions. It is necessary to involve all interested parties: budgetary organizations, universities, private enterprises, research institutes, etc. The solution to the problem of financing can be the attraction of private investment by the State, while creating a certain monopoly, which it regulates by establishing a tariff barrier, above which interested parties cannot determine the cost of their services. This tool allows expanding the market.It motivates investors to modernize their ways of making a profit as well. Long-term debt financing can be another means for introducing smart technologies. In some cases it is necessary to provide targeted funding. All this can be a topic for further research to address the issue of introducing smart technologies within the framework of the formation of the sustainable developmentconcept.

\section{Conclusion}

As a result of the economic efficiency analysis when using smart technologies in the form of a weather control unit in an apartment building, it is possible to formulate the practical results of the project. 1) The installation of this equipment can be considered expedient, since the payback period of the weather control unitservice life is only 5.5 months compared with 12-15 years declared by manufacturers. 2) According to the results of our research, it is necessary to highlight the energy-efficient capabilities of these smart technologies used in the housing and communal sector. During the heating season, 362 Gcal were saved.This result is a high indicator of energy savings. Smart technologies have been successfully implemented in weather control nodes, which have high indicators of energy efficiency, resource conservation and economic benefits. The research results can be used to improve the management processes of apartment buildings and create comfortable living conditions for the population in the conditions of a stable regional economy.

\section{References}

1. A. Meijer, M. P. R. Bolívar, Governing the smart city: A review of the literature on smart urban governance, International Review of Administrative Sciences, 82(2), 392408 (2016)

2. A. Caragliu, C. Del Bo, P. Nijkamp, Smart cities in Europe. Journal of Urban Technology, 18(2), 65-82 (2011)

3. E. Araral, Why do cities adopt smart technologies? Contingency theory and evidence from the United States, Cities, 106(2) (2020) DOI: 10.1016/j.cities.2020.102873

4. H. Gimpel, V. Graf, V. Graf-Drasch, A comprehensive model for individuals' acceptance of smart energy technology - A meta-analysis, Energy Policy, 138(3) (2020) DOI: $10.1016 /$ j.enpol.2019.111196 
5. M. Chen, A. Sinha, K. Hu, M. I. Shah, Impact of technological innovation on energy efficiency in industry 4.0 era: Moderation of shadow economy in sustainable development. Technological Forecasting and Social Change, 164(3) (2021)

6. P. Pelli, Service innovation and sustainable construction: analyses of wood vis-à-vis other construction projects, Cleaner Engineering and Technology,16(2) (2021)

7. D. Mikulić, S. Slijepčević, G. Buturac, Energy renovation of multi apartment buildings: Contributions to economy and climate changes, Energy and Buildings, 25(6) (2020) DOI: $10.1016 /$ j.enbuild.2020.110247

8. Z. Xia, Q. Abbas, Ge Song, Trilemma among energy, economic and environmental efficiency: Can dilemma of EEE address simultaneously in era of COP 21, Journal of Environmental Management, 3(9) (2020) DOI: 10.1016/j.jclepro.2020.124729

9. A. Synnefa, K. Vasilakopoulou, M. Santamouris, Transformation through Renovation: An Energy Efficient Retrofit of an Apartment Building in Athens, Procedia Engineering, 25(9) (2017) DOI: 10.1016/j.proeng.2017.04.260

10. D. D. Kim, H. S. Suh, Heating and cooling energy consumption prediction model for high-rise apartment buildings considering design parameters, Energy for Sustainable Development, 13(1) (2021) DOI: 10.1016/j.esd.2021.01.001

11. F. Kuznik, O. Opel, K. L. Wolfgang, Ruckermal energy storage for space heating and domestic hot water in individual residential buildings, Advances in Thermal Energy Storage Systems, 3(9) (2020)

12. O. V. Bakhareva, A. I. Romanova, L. F. Talipova, S. F. Fedorova, T. A. Shindina, On the building information modeling of capital construction projects market development, Journal of Internet Banking and Commerce, 21(3) (2016) DOI: 10.1088/1757$899 \mathrm{X} / 786 / 1 / 012029$

13. S. Gilani, W. O'Brien, H. B. Gunay, Simulating occupants' impact on building energy performance at deferent spatial scales, Building and Environment, 132, 327-337 (2018)

14. D. O. Burkeev, A. I. Romanova, A. A. Murafa, O. V. Maksimchuk, A. V Voronin, Innovation Technology Implementation in Facility Services in Russia, UERN, 1 (2020)

15. E. V. Ilina, A. I. Romanova, Operational services management in the context of sustainable development of intelligent technologies, IOP Conference Series, 890, 012183 (2020) DOI : 10.1088/1757-899X/890/1/012183

16. A. N. Afanasyeva, S. F. Fedorova, Availability of innovative housing from the perspective of sustainable construction, IOP Conference Series, 890, (2020) DOI: 10.1088/1757-899X/890/1/012182

17. E. V. Ilina, A. I. Romanova, O. V. Maksimchuk, A. V. Voronin, Development of the construction industry in the context of import substitution: Russian experience, Espacios, 38(48), 18 (2017)

18. Y. Rao, The Sustainable Development Goals, Organizational Learning and Efficient Resource Management in Construction, Resources, Conservation and Recycling, 13(6) (2020)

19. S. Kwatra, A. Kumar, P. Sharma, A critical review of studies related to construction and computation of Sustainable Development Indices, Ecological Indicators, 112(5) (2020)

20. A. I. Romanova, G. M. Zagidullina, A. N. Afanasyeva, R. S. Hkairetdinova, Experience in the region to increase the availability of housing services, Mediterranean Journal of Social Sciences. 6(4), 549-554 (2015) DOI: 10.5901/mjss.2015.v6n4s2p549

21. E. Shagiakhmetova, O. Borovskikh, A. Nizamova, T. Kazymova, Multivariate model of construction project operational efficiency, IOP Conference Series, 890, 012113 (2020) DOI: $10.1088 / 1757-899 X / 890 / 1 / 012113$ 